\title{
Do Institutions Matter for Foreign Direct Investment?
}

\author{
Fathi Ali ${ }^{*}$, Norbert Fiess and Ronald MacDonald \\ Department of Economics, University of Glasgow, Glasgow, Scotland, UK \\ $11^{\text {th }}$ July 2008
}

\begin{abstract}
In this paper the role of institutions in determining foreign direct investment (FDI) is investigated using a large panel of 107 countries during 1981 and 2005. We find that institutions are a robust predictor of FDI and that the most significant institutional aspects are linked to propriety rights, the rule of law and expropriation risk. Using a novel data set, we also study the impact of institutions on FDI at the sectoral level. We find that institutions do not have a significant impact on FDI in the primary sector but that institutional quality matters for FDI in manufacturing and particularly in services. We also provide policy implications for institutional reform.
\end{abstract}

Keywords: Foreign direct investment, institutions, sectoral FDI

JEL classification: F3, F4

\footnotetext{
* Correspondence Address: University of Glasgow, Department of Economics, Adam Smith Building, Glasgow, G12 8RT, United Kingdom., Tel.+44-141-3305964, e-mail: f.ali.1@research.gla.ac.uk.
} 


\section{Introduction}

The importance of social-political factors in determining foreign direct investment (FDI) has long been understood and emphasized in the economic literature. For example an early study by Basi (1963) investigated the effects of political instability on FDI. More recently, the literature has become increasingly concerned with the question of: to what extent do improvements in institutional quality help attract more FDI? More specifically, the recent literature has involved three developments: (1) following the influential study of North (1990), the importance of institutions in shaping incentives for investment and economic growth; (2) with the strong growth of FDI flows during the 1990s, transition and developing countries have become particularly interested in institutional reform as a means of attracting larger shares of FDI flows; (3) finally, foreign investors are become increasingly interested in institutional quality when deciding in which country to invest (Bevan et al 2004).

Policy reformers often claim that countries with good institutions attract more FDI. According to recent surveys of the relevant literature, nevertheless, there has been no clear evidence in favour of institutions. For example, Lim (2001) states that the empirical results in this regard are mixed. He also notices that evidence on regulatory, bureaucratic red tape and judicial transparency are less encouraging compared with that on political risk. Blonigen (2005) provides some examples of evidence in favour of institutions and some evidence against institutions, concluding that more convincing evidence requires more studies in the future. Both of the authors attribute the inconclusive evidence to various measurement, conceptual, and methodical problems in the empirical literature. 
More recently, evidence in favour of the FDI/ institutions link (Globerman and Shapiro (2002), Busse and Hefeker (2005), Bènassy-Quèrè et al (2005)) seems to be mounting, although no conclusive result has yet been established. This paper adds to this emerging literature by addressing the following questions: (1) How robust are institutions as a determinant of FDI? (2) What is the relative importance of institutions compared to other determinants of FDI? (3) Which institutional aspect matters most for FDI flows? (4) Are institutions equally important for all types of FDI?

Based on a large set of control variables and estimation techniques robust to endogeneity, we report that institutions are a highly significant and robust determinant of FDI. We find that the impact of institutions on FDI is comparable to that of macroeconomic stability and greater than the impact of taxation and infrastructure quality. We also identify property rights as the institutional aspect that matters most for foreign investors, and, finally, demonstrate that institutions do not matter for FDI in the primary sector, but they have a significant impact on FDI in manufacturing and in particular on FDI in services.

The remainder of this paper is organised as follows: section two discusses some of the important theoretical arguments linking institutions to FDI and critically reviews the recent empirical literature. Section three presents the empirical results and section four concludes. 


\section{FDI and institutions: a theoretical and empirical overview}

What does theory tell us about the impact of institutions on FDI? To provide a theoretical perspective, we combine lessons from the literature on FDI determinants with the literature on institution and investment. While Dunning's (1993, 2001) eclectic paradigm (also: OLI paradigm) provides a framework to study the determinants of FDI, North (1990) establishes a link between institutions and investment. Dunning's paradigm has been primarily developed to study the behaviour of multinational enterprises; i.e. to answer the question why domestic firms own foreign production facilities. However, it has also been widely used to study the determinants of FDI inflows (Gastanaga et al 1998). North's views on institutions are mainly about the impact of institutions on economic activity and investment, but institutions are important for both domestic and foreign investors (Bevan et al 2004).

\subsection{The eclectic paradigm and the determinants of FDI inflows}

According to Dunning (1993; 2001), a firm needs to meet three conditions to become a multinational enterprise (MNE): (1) it needs to possess certain assets that firms in the host country do not have. This so-called ownership advantage is necessary to compensate firms for additional costs of operating in a foreign market place (e.g. costs of dealing with foreign administrations, regulatory and tax systems, and customer preferences). Ownership advantages can be embedded in tangible assets, like patented products or production processes, or in intangible ones, such as managerial, marketing, and entrepreneurial skills. (2) If the firm satisfies the first condition, it must find to its benefit to exploit the ownership advantages through FDI and to keep them internally rather than selling them on or leasing them in order to prevent the 
asset from being replicated by competitors. This advantage is called internalization advantage. (3) Firms must finally find it profitable to combine ownership and internalization advantages with some locational advantage in the host country. Without such country-specific locational advantage, foreign markets could be served exclusively through exporting.

Dunning identifies several locational advantages that make some countries a more attractive destination for multinational enterprises. These include the availability of natural resources; quality and prices of inputs; infrastructure quality; investment incentives; the economic system and strategies etc. (Dunning 1993; 1998). Dunning (2001) does not provide a definitive list of locational advantages but stresses that any factor can become a locational advantage if it affects the profitability of establishing a production facility in the host country. Such a flexible interpretation of the eclectic paradigm has led to the compilation of a long list of potential determinants of FDI, which has also raised questions about the paradigm's value as an analytical tool. Perhaps even more of a drawback for empirical analysis, the paradigm does not provide a clear theoretical expectation about the relative importance of different determinants, which leaves empirical testing as the only means for assessing the relative importance of different FDI determinants. Moreover, the paradigm assumes that some determinants may affect all types of FDI, although to a varying degree, while other determinants may only affect some specific forms of FDI. For example, tariffs may encourage market-seeking FDI but discourage efficiency or export seeking FDI. Furthermore, market size, will matter for market-seeking FDI but not for natural resource seeking FDI. 


\subsection{Institutions and FDI}

North (1990) defines institutions as the rule of the game in a society. According to this definition the institutional framework consists of all kinds of humanly devised constraints that shape human interactions, including economic exchange. Institutions can be formal (e.g. constitutions, laws etc.), or informal (e.g. conventions and customs). Institutions are created to reduce the uncertainty associated with human interaction and exchange, and to establish a behavioural norm. Institutions therefore provide societies with a predictable framework for interaction.

North argues that institutions affect economic activities through transaction and production costs: good institutions help to lower the cost of doing business and hence increase profitability and economic activity. Parties at opposite ends of an economic exchange have incomplete information about their counterparts' true intentions, who might decide to cheat, shirk or renege on an agreement. Due to such information uncertainty, transaction costs contain a risk premium. North argues that the risk premium is a function of institutional quality as it depends on the degree of contract enforceability; the protection of property rights; and the likelihood of defection by the opposite party. The size of the risk premium is not only a function of institutional quality, it also determines the scale of economic exchange in an economy: when property rights are poorly protected and contracts enforcement is difficult, then risk premium will be high and economic activity will be limited to direct interpersonal exchange rather than complex impersonal trade.

Institutions affect economic activities also via production costs (North, 1990). Institutions matter for production as they affect a firm's environment. To illustrate, if 
input markets lack good institutions, more time and resources will need to be devoted to monitoring and metering. Institutions can also affect production costs if inefficient institutions cause costly production delays; this can be the case if lengthy waiting times or bribes are required to receive certain kinds of permits or public services.

As institutions impact the profitability in the host country, they can present a significant locational advantage for multinational enterprises. Dunning (1998) argues that recent developments in the global economy have changed MNEs' perception of locational advantages; MNEs increasingly prefer locations that offer the best economic and institutional facilities. The focus of MNEs has reportedly shifted from traditional locational advantages, e.g. labour cost or the availability of natural resources to so-called creative locational advantages which include knowledge-based assets, infrastructure and institutions (Narula and Dunning, 2000; Bevan et al 2004).

Henisz and Williamson (1999) provide yet a further argument why institutional quality matters for FDI. Henisz and Williamson (1999) and Henisz (2000) stress that in countries where property rights are poorly protected, MNEs often face expropriation risks. For example, the government of the host country may be tempted to appropriate some of returns of the MNEs or even nationalize them. Moreover, firms in the host country may be able to persuade their government to favour at the expense of MNEs.

\subsection{Review of empirical evidence}

This subsection reviews the recent cross-country empirical evidence on the impact of institutions on FDI. Table 1 provides an overview of the different studies in terms of country samples, time periods, and institutional variables used; it also summarizes the 
main findings. The literature appears to offer several lessons. First, the majority of studies find that institutions, however defined or measured, matter for FDI. However, this conclusion is not shared by Asiedu (2002), Noorbakhsh et al. (2001), Harms and Ursprung (2002) and June and Singh (1996). Asiedu (2002) finds that neither political risk nor expropriation risk has a significant impact on FDI and Noorbakhash et al (2001) fails to establish a link between democracy and political risk and FDI. Harms and Ursprung (2002) and June and Singh (1996) find that the effects of institutions on FDI are not robust.

(Insert table 1 about here)

The failure of these studies to identify any significant impact of institutions on FDI could be due to either sampling or measurement issues. Studies that tend to reject any significant impact of institutions on FDI are generally based on rather small country samples. ${ }^{1}$ Campos and Kinoshita (2003) highlight that the effect of a particular variable can be underestimated in a small sample if this variable exhibits limited variation within that particular sample. As institutional indicators usually exhibit little time variation, inference on their impact should ideally be based on large samples, which represent the whole global market, rather than a subset.

Measurement problems result when a single index is used to capture a broad, complex factor such as institutions. Foreign investors are likely to base their investment decisions on overall institutional quality rather than a single institutional aspect such as democracy or corruption. For example, a democratic country may have a high level of corruption or vice versa. Thus, using an index that captures only one aspect of

\footnotetext{
${ }^{1}$ For example, Noorbakhsh et al (2001) use 36 developing countries, June and Singh (1996) use 31 countries, and Harms and Ursprung (2002) use 62 countries.
} 
institutions as a proxy for overall institutional quality is likely to underestimate the role of institutions in determining FDI; a comprehensive measure of institutional quality allows for a more complete assessment of the role of institutions on determining FDI inflows.

Second, despite an apparent consensus that institutions matter for FDI, the literature provides little guidance about the relative importance of institutional reform as mean to attract FDI. Policy makers may be interested in whether institutional reform has a larger pay-off than other policies in terms of attracting FDI. With the exception of Gastanaga et al (1998) and Asiedu (2005), the extant literature offers little insight as to how institutional quality ranks relative to other policy measures for attracting FDI. Gastanaga et al (1998) investigate if policy and institutional variables have any impact on FDI. They find institutional variables like contract enforcement, nationalization risk, and bureaucratic delay to have significant effects on FDI, but they do not try to compare them with the impact of other variables. The exception from this is corruption. They find that a doubling in the corruption index has an effect on FDI inflows that is approximately equal to a percent increase in the corporate tax rate, but this result is not robust. Asiedu (2005) compares the impact of institutions with the impact of non-policy variables, such as the availability of natural resources and market size of FDI, and concludes that countries that are small or lack natural resources can increase FDI by improving institutions. Both of the studies use rather limited country samples, which make their results difficult to generalize.

Third, there is little agreement on which institutional aspect matters most for FDI. Jensen (2003) stresses that democracy and other political institutions are the most relevant institutional aspects for FDI. Li and Resnick (2003) on the other hand find 
that democracy loses out to property rights, once the latter are included. This ambiguity calls for further investigation to establish which institutional aspect matters most for FDI. Such an investigation has considerable policy implications. If FDI is predominately affected by institutional aspects that can be considered “exogenous” to the current political establishment (e.g. democracy and other political institutions which would require constitutional change or a change of the ruling political elite), policy choices - short of regime change - are limited. However, if FDI is primarily related to more readily changeable "endogenous" institutional aspects, such as rule of law or bureaucratic quality, governments have greater policy space to attract FDI by reforming these institutional aspects. A larger sample and the grouping of single institutional indices into homogenous categories that capture major institutional aspects can help identify which institutional aspects are most conducive to FDI.

Fourth, some authors appear to agree that the impact of institutions on FDI differs by sector. Asiedu (2002), for example, argues that the insignificance of political risk in her study may well be explained by the high profitability of FDI geared towards the oil sector which more than compensates for political risk. Busse (2004) alludes to an important change in the relationship between democracy and FDI. While in the 1970s and 1980s, democracy has not been significant and was even in the 1970s negatively associated with FDI, the relationship appears to have turned positive and significant in the 1990s. Busse mainly attributes this result to a shift in the decomposition of FDI flows to developing countries, where FDI is being increasingly attracted by manufacturing and services, rather than the primary sector. Spar (1999) argues that FDI in the primary sector may not be sensitive to institutional quality in the host country: as resource-seeking FDI depends on the availability of raw materials, compared to other kinds of FDI, choices are greatly limited when picking between 
alternative investment sites. Referring to Spar’s (1999) views, Busse (2004) argues that initial FDI flows to developing countries were often geared towards the exploitation of raw materials and both MNEs and host governments saw it in their best interest to collaborate through rent-sharing; this usually entailed that the host country would mainly focus on protecting and maintaining investors' access to the natural resource.

To our knowledge there has been no systematic attempt to study the impact of institutions on FDI by sectoral allocation. This has been largely due to lack of data on sectoral FDI. However, with the recent publication by UNCTAD of sectoral level data on FDI inflows, we are able to fill this gap in the literature.

\section{Empirical analysis}

This section describes the data and methodology. It also presents empirical results and discusses policy implications

\subsection{Design Issues}

There are two key issues that have to be addressed in any empirical investigation of the impact of institutions on FDI, namely: the appropriate model specification and endogeneity bias. Theory offers no clear-cut guidance for model specification. While the OLI paradigm has become central for most empirical work, it does not, as already mentioned, specify a definite set of FDI determinants. In a reflection on the empirical literature Moosa and Cardak (2006) critique that in the search for FDI determinants researchers often report the most appealing results to suit their specific research aims. Some studies are more careful and, for example, Chakrabarti (2001), apply extreme 
bound analysis to assess the robustness of different determinants of FDI. Chakrabarti (2001) reports market size (measured as GDP per capita) as the most robust determinant of FDI and finds that trade openness is more likely to be correlated with FDI than any other potential FDI determinant. Building on this finding, and on the fact that most empirical studies includes market size and trade openness in their model specifications, we start from a parsimonious model specification that includes only market size, trade openness, and an index for institutional quality. We then add other potential FDI determinants to test the robustness of the results. Our basic model specification is:

$$
F D I=\beta_{0}+\beta_{1} G D P+\beta_{2} \text { Trade }+\beta_{3} \text { Inst }+\beta_{4} V+u
$$

Where FDI is the log of foreign direct investment per capita, GDP is the log of GDP per capita; Trade is trade (imports and exports) as a ratio of GDP, Inst refers to the ICRG Index, and $V$ is a vector of other controlling variables. In the basic model specification $\beta_{4}$ is set to zero.

The second difficulty that any empirical analysis on FDI determinants faces is that of endogeneity, which can bias estimated coefficients and cause invalid statistical inference. Endogeneity arises from the simultaneity between FDI and its determinants: as FDI is likely to increase economic activity in the host countries, a host country's GDP per capita and measures of trade are likely to be endogenous; institutions are also feasibly endogenous. The literature on institutional change indicates that economic outcomes may impact institutions. From this line of reasoning, it seems feasible to argue that FDI potentially affects institutions in the host country. To mitigate against endogeneity bias all endogenous variables have been 
lagged by one period, i.e. five years. We also report results based on difference and system GMM where lagged differences and levels of endogenous variables are used as instruments to control for endogeneity.

\subsection{Description of variables and data sources}

Our analysis is based on 107 countries and covers the period from 1981 to 2005. Data availability restricts model specifications and sample sizes in some cases. But even the most restrictive model specification still includes close to 50 countries. Appendix A provides variable definitions and data sources. In line with other studies we use FDI per capita, FDI, as our dependent variable, which is the log of net inflows of foreign direct investment per capita in USA dollar. The International Country Risk Guide Index, ICRG is used to proxy institutional quality.

The ICRG index has several advantages over other measures of institutional quality. First, it provides an assessment of institutional quality for 142 countries over the period 1984-2005. This enlarges the sample and allows us to perform panel estimations. Moreover, the ICRG provides information on 12 dimensions of institutional quality, which can be used to construct a collective indicator that captures the quality of the overall institutional environment. These 12 indicators can also be grouped in homogenous categories to proxy specific aspects of institutions, such as the protection of propriety rights. This flexibility enables us to study the general effect

of institutions on FDI and to compare it with the effects of other policy-related determinants of FDI. It is also enables us to identify institutional aspects most closely related to FDI. 


\subsection{The empirical results}

In this section we report the results of our panel analysis. Table 2 summarises the findings from different model specifications, starting with Model 1, which is the basic model specification according to (1). Subsequent models add different control variables to the basic model specification.

Model 1 is based on a random effect specification of the basic model. This specification is supported by a Hausman test, reported in table 2. In this model all the explanatory variables have the correct signs and are significant at the $1 \%$ level: countries with larger markets, higher degrees of openness, and better institutional quality received more FDI. This finding indicates that after controlling for market size and degree of openness, countries with better institutions attract more FDI inflows. In the following models, the basic model specification is augmented by other potential FDI determinants, which have been suggested by the literature. Model 2 adds inflation to capture the impact of macroeconomic stability on FDI. As expected, inflation has a negative impact on FDI and is significant at the 1\% level. Model 3 controls for quality of infrastructure, proxied by telephone mainlines per 1,000 people. As can be seen from the table, infrastructure quality has a significant positive impact on FDI. Model 4 controls for the level of taxation. Taxes appear to have a significant and negative impact on FDI. In model 5 we replace the trade-GDP ratio with a policy-related variable, the mean tariff rate, and in model 6 we additionally expand on the role of market size by including GDP growth rate to control for the impact of potential growth of the market size on FDI. The results show that both tariff rates and GDP growth have a significant impact on FDI, where the tariff term enters with a negative 
sign and growth with a positive sign. More interestingly, institutional quality maintains its significance in all of these model specifications.

(Insert table 2 about here)

In models 7 through 11, we test the sensitivity of model 6 by controlling for further potential FDI determinants. Model 7 shows that exchange rate distortions, measured by the index of the difference between the official and black market exchange rate, have a negative but insignificant impact on $\mathrm{FDI}^{2}$. In model 8, we control for government interventions, measured by government investment as a share of gross investment, and in model 9, we control for wage levels, proxied by the mean wage in manufacturing in current US Dollars. Both government intervention and wage levels have a negative but insignificant impact on FDI. In models 7, 8, and 9 institutional quality maintains its significance.

Models 10 and 11 include human capital and natural resources availability respectively. Human capital, measured by average years of higher schooling in the total population, has a positive and significant impact on FDI. The natural resources availability term, measured by the ratio of primary exports to GDP, has a positive but not significant impact on FDI. However, controlling for these variables does not affect the relevance of institutional quality for FDI. Throughout, all model specifications the

\footnotetext{
${ }^{2}$ Higher values of the exchange rate distortion index means less difference between black market and official exchange rates.
} 
impact of institutions on FDI appears to be insensitive to changes in control variables ${ }^{3}$.

Our results also prove robust to alternative estimation approaches consisting of OLS with panel-corrected standard errors (model 12), difference-GMM (model 13) and system-GMM (model 14) Beyond a robustness check, GMM also allows us to test for agglomeration effects, which have recently been proposed as an additional determinant of FDI.

Models 12 through 14 estimates model 6 by OLS with panel-corrected standard errors, PCSE (model 12), which assumes that disturbances are, by default, heteroskedastic and contemporaneously correlated across panel. The impact of institutions on FDI is still found to be significant after controlling for the possible autocorrelation of the error terms across panels.

In model 13, we control for the impact of agglomeration economies. Recently, several studies have acknowledged that the presence of foreign investors may act as a catalyst to attract further investors (Dunning, 1998). There are several reasons for such agglomeration effect. Firms less familiar with a specific country may take the presence of other foreign firms as a sign for a locational advantage and of high profitability. In addition, new investor may try to benefit from positive externalities, such as knowledge spillovers, specialized labour, and intermediate inputs, resulting from locating their activities next to other firms (Campos and Kinoshita, 2003).

\footnotetext{
${ }^{3}$ We also include other potential determinants of FDI like external debt, domestic investment, government consumption, trade balance. None of these variables affects the significance of institutions. The results are available upon request.
} 
To test the impact of agglomeration economies, we include lagged FDI in the model specification. This changes the model specification to a dynamic panel-data model. Because the lagged dependent variables and the time-unvarying country-specific error terms are correlated, both random and fixed effects models produce inconsistent estimation here. Arellano and Bond (1991) solve this problem by using generalized method of moment GMM. They eliminate the country-specific error term by taking the first difference of the model and then use the lagged levels of the dependent variable as instruments for the first difference of the dependent variable. The same approach can be applied to any endogenous variable within this set of regressors. This technique is often referred to as difference-GMM (Baum, 2005). Arellano and Bover (1995) and Blundell and Bond (1998) acknowledge a potential weakness in difference-GMM, since the lagged levels are often poor instruments for firstdifferenced variables (Baum, 2005). They propose using lagged levels as well as lagged differences as instruments. This technique is usually referred to as system GMM. Both difference and system GMM requires a lack of second-order serial correlation in the residuals of the differenced model. Arellano and Bond developed a test for that and used a Sargan test of over-identifying restrictions to verify the overall appropriateness of instruments.

Models 13 and 14 in table 2 show the results of difference and system GMM, respectively. In both models we treated GDP per capita, GDP growth, and institutions as endogenous variables. We also corrected the potential downward bias in the estimated standard error by using the Windmeijer finite-sample correction (Windmeijer 2005). The results show that the basic assumption of no second-order serial correlation is satisfied in both models and that the Sargan test confirms the validity of the instruments. In both models, lagged FDI has a positive and significant 
impact on FDI and this indicates that agglomeration economies matter for FDI. Interestingly, institutional quality maintains a significant positive impact on FDI even when accounting for agglomeration economies. It is noteworthy that this is not the case for inflation, infrastructural quality, and taxation, which maintain the correct sign, but lose significances. Tariff rate and GDP growth are sensitive to model specification.

Table 2 provides a summary of all model specifications and reveals that institutional quality appears to be a highly robust FDI predictor. The significance of institutions in determining FDI appears not to be sensitive to model specifications, control variables, or estimation technique. The only other consistent predictor of FDI appears to be market size, measured as GDP per capita.

\subsection{The relative importance of institutions}

When competing for FDI, policy makers face a range of policy choices, including macro economic stabilization, tax and tariff reform, and institutional reform. This section attempts a horse race between alternative policies in order to establish which policy has the largest pay-off in terms of FDI.

Comparing the quantitative impact of institutions with that of other policy variable raises the problem of unit measurement and to address this problem, we use beta coefficient analysis. This analysis avoids the problem of unit measurement by standardising regressors, since the beta coefficients measure the impact of a onestandard-deviation change in a given regressor on the dependent variable. This approach allows us to directly compare the impact of different variables on FDI in 
quantitative terms. ${ }^{4}$ Model 15 in table 2 shows beta coefficients for model 12. A one standard deviation increase in institutional quality raises the log of FDI by 0.155 standard deviations according to model 15. Model 15 also indicates that the impact of institutions on FDI is slightly greater than the impact of inflation. And it is greater than the impact of taxation and infrastructure quality and smaller than the impact of tariff rate. This finding seems to suggest that improving institutional quality is as good or even better as all other policy options available to policymakers, except tariff rate, which has an even greater impact on FDI.

\subsection{Which institutional aspect matters most for FDI?}

The empirical literature on the role of institutions places generally little attention on the relative importance of different institutional aspects. Existing studies focus either on a summary index of institutional quality, which encompasses a broad spectrum of institutional aspects, or on particular institutional aspect, such as for example democracy. As it is entirely plausible that certain aspects of institutional quality might matter more for FDI, we attempt to rank in this section the relative importance of property rights, bureaucratic efficiency, and democracy in determining FDI.

For this purpose we split the ICRG comprehensive index along three institutional aspects: (1) A Property Rights index combines Law and Order and Investment Profile. Law and Order assesses the strength and impartiality of the legal system, popular observance of the law, and the effectiveness of sanctions. Investment Profile assesses contract viability, expropriation risk, and profits repatriation. (2) The

\footnotetext{
${ }^{4}$ To compute beta coefficients, all variables included in the regression (regressors as well as dependent variable) are standardised by subtract the mean of each variable and divide it by its standard deviation. Beta coefficients are sometimes also referred to as standardised coefficients.
} 
Bureaucratic Efficiency index combines Corruption and Bureaucracy Quality. Both assess the strength and quality of the bureaucracy and the extent to which bureaucracy is autonomous from political pressure and free from corruption. (3) The Democracy index combines Military in Politics and Democratic Accountability and reflects checks \& balances within the political system, and the extent of military involvement in politics. ${ }^{5}$

To assess the impact of different institutional aspects on FDI, we replaced the comprehensive index in model 6 with the three sub-indexes of institutional quality above. And to ensure robustness of our findings, Table 3 reports estimates based on random effects (Model 1), OLS with panel corrected standard errors (Model 2), difference GMM (Model 3) and system GMM (Model 4).

(Insert table 3 about here)

In models 1 and 2 GDP per capita, GDP growth and institutional variables are lagged by one period to reduce any potential bias due to endogeneity. We find that property rights are the only institutional dimension that seems to matters for FDI; bureaucratic efficiency and democracy are not found to be a significant determinant of FDI. This finding is robust to model specifications.

This result is in line with for example Noorbakhash et al (2001) who fail to establish a link between democracy, political risk and FDI; it possibly also explains why Harms and Ursprung (2002), and June and Singh (1996), using a composite indicator of institutional quality fail to establish robust effects of institutional quality on FDI.

\footnotetext{
${ }^{5}$ Our indices for property rights, bureaucratic efficiency and democracy combine the underlying ICRG sub-indices with equal weighting.
} 


\subsection{The role of institutions: evidence by sector}

Asiedu (2002) and Busse (2004) suggest that the impact of institutions on FDI may vary by sector allocation. Asiedu (2002) argues that political risk is less relevant for FDI in the oil sector. Busse (2004) argues that democracy matters more for FDI in manufacturing and services but less for FDI in the primary sector.

In this section we empirically investigate the sector-specific impact of institutions on FDI. To maximise country coverage, we combine two comparable data sources on sectoral FDI: OECD's the International Direct Investment Statistics Year Book and UNCTAD's World Investment Directory. We first report unconditional contemporaneous correlations between the ICRG institution index and sectoral FDI. Table 4 provides first support for Spar (1999)'s hypothesis that FDI in primary sector may not be sensitive to institutions. The relation between institutions and FDI into both manufacturing and services is significantly stronger.

(Insert table 4 about here)

We next report conditional correlations between institutions and sectoral FDI by including other potential sector-specific FDI determinants. Bar a few studies, the empirical literature on sectoral determinants of FDI is virtually non-existent. As such, there is little guidance on appropriate control variable, in particular with respect to FDI into the primary sector.

Dunning (1993) argues that locational advantages for natural resource-seeking FDI include the availability of the resource; the quality of infrastructure; and the level of taxation. Market size and the degree of openness arguments appear less relevant for 
FDI into the primary sector, but are identified as important for FDI for manufacturing (Root and Ahmend, 1979) and services (Kolstad and Villanger, 2004). Root and Ahmed (1979) test the role of value-added in manufacturing and manufactured imports both as shares of GDP as determinants of FDI into manufacturing, and they find them insignificant. Kolstad and Villanger (2004) find that trade openness and FDI into manufacturing is positively correlated with FDI into services.

Taking this into consideration, we model FDI into the primary sector as a function of the availability of natural resources; the quality of infrastructure; and the tax level. Following Sachs and Warner (1995) exports of raw material as per cent of GDP is used as proxy for the availability of natural resource. As before, we use the number of telephone lines per 1000 people as a proxy for infrastructure quality.

We specify FDI into manufacturing as a function of the value-added in manufacturing as a percent of GDP; the degree of openness; the rate of economic-wide inflation, infrastructure quality, and tax level. FDI into services is specified as a function of the value-added in services as percent of GDP; the degree of openness; the rate of economic-wide inflation, infrastructure quality, and tax level. Since services FDI might be driven by manufacturing FDI (Kolstad and Villanger (2004)), we also include manufacturing FDI in the service FDI regression.

Table 5 presents the findings for FDI into the primary sector. We find that the positive effect of institutions on primary sector FDI looses significance once we control for other determinants. The availability of natural resource and low levels of taxation are therefore much more relevant for attracting primary sector FDI than institutional quality, which is not significant. 
(Insert table 5 about here)

Tables 6 and 7 show that institutions clearly matter for FDI in manufacturing and services FDI. More interestingly, the role of institutions in determining FDI into services seems stronger than for manufacturing FDI. Modes 1 in Tables 6 and 7 show that institutions have more power in explaining FDI in services than in explaining manufacturing FDI. Furthermore the coefficient on institutions in the regression on services FDI is larger and more significant compared to the regression on FDI in manufacturing.

(Insert table 6 and 7 about here)

This result has the following policy implications. First, for a country that tries to attract FDI into the primary sector, improving the quality of infrastructure and reducing tax levels is more relevant than institutional reform. Second, institutional reform can attract more FDI inflows into services than manufacturing. Third, and more importantly, the increasing share of FDI into the service sector at the expense of both primary and manufacturing FDI in recent years, as evident from Table 8, implies that institutional reform becomes an increasingly important tool for countries that try to increase their share in FDI inflows.

(Insert table 8 about here)

\section{Conclusion}

This paper assesses the impact of institutions in determining FDI inflows and provides policy lessons for institutional reform. To robustify our results, we apply different 
econometric techniques and a large panel of countries. The main results of our paper can be summarized as following:

First, institutions appear to be a robust determinant of FDI inflows. Institutions appear to have a consistent effect on FDI under different model specifications and various controlling variables.

Second, the most relevant institutional aspects for FDI appear to be those linked to the protection of property rights such as rule of law and expropriation risk, all of which are institutions which are changeable in the short to medium-run. This implies that policy makers stand a good chance of attracting FDI inflows by strengthening the legal and judicial system.

Third, regarding the impact of institutions on FDI by sector, it appears that institutions do not matter much for FDI into the primary sector. However, institutional quality matters for FDI in manufacturing and to an even greater extent for FDI in services. As such, institutional reform is unlikely to attract FDI into the primary sector, but likely to benefit FDI into manufacturing and services. As services FDI are accounting for a ever greater share in total FDI, the importance of institutional reform as a policy tool for attracting FDI in general may even increase in coming years.

Finally, compared with other relevant policy variables, institutional reform appears to be an important option for attracting FDI. Indeed the improvement of institutions appears as important as macroeconomic stability in this regard and better institutions appear to matter even more than improvements in infrastructure or tax cuts. 


\section{Bibliography:}

Acemoglu, D., Johnson, S. \& Robinson, J. (2001). The colonial origins of comparative development: an empirical investigation. American Economic Review, (91), 1369-401.

Addison, T. \& Heshmati, A. (2003). The new global determinants of FDI flows to developing countries: The importance of ICT and democratization. Discussion paper No.2003/45. World institute for development economic research, United Nations University, Helsinki.

Altomonte, C. (2000). Economic determinants and institutional frameworks: FDI in economies in transition. Transnational corporations, (9). 75-106.

Arellano, M. \& Bond, S. (1991). Some tests of specification for panel data: Monte Carlo evidence and an application to employment equation. Review of economic studies, (58), 277-97.

Aron, J. (2000). Growth and institutions: A review of the evidence. World Bank Research Observer, 15, 99-135.

Asiedu, E. (2002). On the determinants of foreign direct investment to developing countries: is Africa different? World Development, 30(1), 107-119.

Asiedu, E. (2005). Foreign direct investment in Africa: the role of natural resources, market size, government policy, institutions and political instability. WIDER Research paper No.2005/24. World institute for development economic research, United Nations University, Helsinki.

Barro, R.(1996). Democracy and growth. Journal of economic growth, (1), 1-27.

Basi, R. (1963). Determinants of United States private direct investment in foreign countries. Kent State University Press.

Baum, C. (2005). An Introduction to Modern Econometrics Using Stata. Stata press Publication: Texas.

Benassy-Quèrè, A., Coupet, M. \& Mayer, T. (2005). Institutional determinants of foreign direct investment. CEPII Working paper No 2005-05. Centre d'Etudes Prospectives et d'Informations Internationales.

Bevan, A., Estrin, S. \& Meyer, K. (2004). Foreign investment location and institutional development in transition economies. International business review, (13) , 43-64.

Blonigen, B. A. (2005). A review of the empirical literature on FDI determinants. NBER Working Paper No. 11299, National Bureau of Economic Research, Cambridge, MA. 
Brunetti, A. \& Weder, B. (1998). Investment and institutional uncertainty: A comparative study of different uncertainty measures. Weltwirtschaftliches Archiv, (134), 513-33.

Busse, M. (2004). Transnational corporations and repression of political rights and civil liberties: An empirical analysis. Kyklos, (57), 45-66.

Busse, M. \& Hefeker, C. (2005). Political risk, institutions and foreign direct investment. HWWA Discussion paper No.315, Hamburg Institute of International Economics, Hamburg.

Campos, N.F. \& Kinoshita, Y. (2003). Why does FDI go where it does? New evidence from the transition economies. IMF Working paper No.223, International Monetary Fund, Washington.

Chakrabarti, A. (2001). The determinants of foreign direct investment: Sensitivity analyses of cross-country regressions. Kyklos, (54), 89-114.

Drabek, Z. \& Payne, W. (1999). The Impact of Transparency on Foreign Direct Investment. Staff Working Paper ERAD-99-02, World Trade Organization, Geneva.

Dunning, J. (1993). Multinational enterprises and the global economy. Wokingham: Addison-Wesley.

Dunning, J. (1998). Location and the multinational enterprise: A neglected factor? Journal of International Business Studies. (29), 45-66.

Dunning, J. (2001). The eclectic (OLI) paradigm of international production: past, present and future. International Journal of the Economic of Business. (8), 173-190.

Frankle, J. \& Romer, D. (1999). Does trade cause growth. American Economic Review. (89), 379-99.

Gastanaga, V., Nugent, J. \& Pashamova, B. (1998). Host country reforms and FDI inflows: how much difference do they make? World development, (26). 1299-1314.

Globerman, S. \& Shapiro, D. (2002). Global foreign direct investment flows: the role of government infrastructure. World development, (30), 1899-1919.

Harms, P. \& Ursprung, H. W. (2002). Do civil and political repression really boost foreign direct investment? Economic Inquiry, 40, 651-663.

Hall, R. \& Jones, C. (1999). Why do some countries produce so much more output per worker than others? Quarterly journal of economics, (114), 83-116.

Henisz, W. \& Williamson, E. (1999). Comparative economic organization-within and between countries. Business and politics, (1), 261-77.

Henisz, W. (2000). The institutional environment for multinational investment. Journal of Law, Economics and Organization, (16), 334-364. 
Kolstad, I. \& Tondel, L. (2002). Social development and foreign direct investment in developing countries, CMI Report 2002:11, Chr Michelsen Institute, Bergen.

Kolstad, I. \& Villanger, E. (2004). Determinants of foreign direct investment in services, Working Paper 2004:2, Chr Michelsen Institute, Bergen.

Knack, S. \& Keefer, P. (1997). Does social capital have an economic payoff? A crosscountry investigation. The quarterly journal of economics,(112), 1251-1288.

Jensen, N. (2003). Democratic governance and multinational corporations: Political regimes and inflows of foreign direct investment. International organization, (57), 587-616.

Jun, K. \& Singh, H. (1996). The determinants of foreign direct investment in developing countries. Transnational corporations, (5), 67-105.

Jutting, J. (2003). Institutions and Development: A Critical Review. OECD Tecchnical Paper No.210. OECD Development Centre, Paris.

Li, Q. \& Resnick, A. (2003), Reversal of fortunes: democratic institutions and foreign direct investment inflows to developing countries. International Organization, 57, 175-211.

Lim, E.G. (2001). Determinants of, and the relation between, foreign direct investment and growth: a summary of the recent literature. IMF Working Paper No.175, International Monetary Fund, Washington.

Meon, P. \& Sekkat, K. (2004). Does the quality of institutions limit the MENA's integration in the world economy? The world economy, (7), 1475-1498.

Moosa, I. \& Cardak, B. (2006). The determinants of foreign direct investment: An extreme bounds analysis. Journal of multinational financial management, (16), 199211.

Mudambi, R. \& Navarra, P. (2002). Institutions and internation business: a theoretical overview. International business review, (11), 635-646.

Narula, R. \& Dunning, J. (2000). Industrial development, globalization and multinational enterprises: New realities for developing countries. Oxford Development studies, (28), 141-167.

Noorbakhsh, F., Paloni, A. \& Youssef, A. (2001). Human capital and FDI inflows to developing countries: New empirical evidence. World development, (29), 1593-1610.

North, D.C. (1990). Institutions, Institutional change and economic performance. Cambridge: Cambridge University Press. 
Root, F. \& Ahmed, A. (1979). Empirical determinants of manufacturing direct foreign investment in developing countries. Economic development and cultural change, (27), 751-767.

Sachs, J. \& Warner A. (1995). Natural resource abundance and economic growth. NBER Working Paper No. 5398, National Bureau of Economic Research, Cambridge,MA.

Schneider, F. \& Frey, B. (1985). Economic and political determinants of foreign direct investment. World development, (13), 161-175.

Spar, D. (1999). Foreign investment and human rights. Challenge, (42), 55-80.

Stein, E. \& Daude, C. (2001). Institutions, integration and the location of foreign direct investment, paper presented at Annual meeting of the board of governors, InterAmerican Development Bank and Inter-American Investment Corporation, Santiago de Chile.

Stobaugh, R. (1969). Where in the world should we put that plant? Harvard business review,(47), 129-36.

Svensson, J. (1998). Investment, property rights, and political instability: theory and evidence. European economic review, (42), 1317-41.

Wei, S. J. (2000a). How taxing is corruption on international investors? Review of Economics and Statistics, 82, 1-11.

Wei, S. J. (2000b). Local corruption and global capital flows. Brookings paper on economic activity, (20), 303-346.

Wheeler, D. \& Mody, A. (1992). International investment location decisions: the Case of U.S. firms. Journal of international economics, (33), 57-76.

Windmeijer, F. (2005). A finite sample correction for the variance of linear efficient two-step GMM estimators. Journal of Econometrics, (126) 25-51. 


\section{Appendix A: Definition of Variables and Data Sources}

\begin{tabular}{|c|c|c|}
\hline Variable & Definition & Source \\
\hline FDI & $\begin{array}{l}\text { Log of Foreign direct investment per capita, net } \\
\text { inflows, current US\$ }\end{array}$ & UNCTAD, FDI database. \\
\hline GDP & Log of GDP per capita, (current US\$) & $\begin{array}{l}\text { World } \quad \text { Bank, } \\
\text { Development Indicators. }\end{array}$ \\
\hline Trade Ratio & Log of Merchandise trade (\% of GDP) & $\begin{array}{l}\text { World } \quad \text { Bank, } \\
\text { Development Indicators. }\end{array}$ \\
\hline GDP Growth & GDP Growth (annual \%) & $\begin{array}{l}\text { World } \quad \text { Bank, } \\
\text { Development Indicators. }\end{array}$ \\
\hline Institutions & ICRG Index, 0-100 scale & PRS Group \\
\hline Inflation & Consumer prices (annual \%) & $\begin{array}{l}\text { World } \quad \text { Bank, } \\
\text { Development Indicators. }\end{array}$ \\
\hline Income Tax & Top Marginal Income Tax Rate. & $\begin{array}{l}\text { Economic Freedom of the } \\
\text { World, } 2006 \text { Annual Report. } \\
\text { The Fraser Institute. }\end{array}$ \\
\hline Tariff & Mean tariff rate. & $\begin{array}{l}\text { EFW, } 2006 \text { Annual Report. The } \\
\text { Fraser Institute. }\end{array}$ \\
\hline $\begin{array}{ll}\text { Exchange rate } \\
\text { distortion }\end{array}$ & $\begin{array}{l}\text { Index of Difference between official exchange } \\
\text { rate and black market rate, } 0-10 \text { scale. }\end{array}$ & $\begin{array}{l}\text { EFW, } 2006 \text { Annual Report. The } \\
\text { Fraser Institute. }\end{array}$ \\
\hline Government Size & $\begin{array}{l}\text { Government investment as a percentage of gross } \\
\text { investment. }\end{array}$ & $\begin{array}{l}\text { EFW, } 2006 \text { Annual Report. The } \\
\text { Fraser Institute. }\end{array}$ \\
\hline Infrastructure & Telephone mainlines (per 1,000 people) & $\begin{array}{l}\text { World Bank, } \\
\text { Development Indicators. }\end{array}$ \\
\hline Human capital & $\begin{array}{l}\text { Average years of higher schooling in the total } \\
\text { population. }\end{array}$ & Barro R. and J.W. Lee.2000. \\
\hline Property Rights & $\begin{array}{l}\text { Simple Average of indices of } \\
\text { Law and Order \& } \\
\text { Investment Profile, scale 0-12. }\end{array}$ & $\begin{array}{l}\text { Calculated from ICRG Data, } \\
\text { PRS Group. }\end{array}$ \\
\hline Bureaucracy & $\begin{array}{l}\text { Simple Average of indices of } \\
\text { Bureaucracy Quality \& Corruption, scale 0-12. }\end{array}$ & $\begin{array}{l}\text { Calculated from ICRG Data, } \\
\text { PRS Group. }\end{array}$ \\
\hline Democracy & $\begin{array}{l}\text { Simple Average of indices of Democratic } \\
\text { Accountability\& Military in Politics, Scale } 0-12 \text {. }\end{array}$ & $\begin{array}{l}\text { Calculated from ICRG Data, } \\
\text { PRS Group. }\end{array}$ \\
\hline Wages & $\begin{array}{l}\text { Wages and salaries in current US Dollars in } \\
\text { manufacturing sector divided by number of } \\
\text { Employees }\end{array}$ & UNIDO, Industrial Statistics \\
\hline $\begin{array}{l}\text { Natural } \\
\text { Resources }\end{array}$ & Ratio of Primary exports to GDP & $\begin{array}{lll}\text { World } & \text { Bank, } & \text { World } \\
\text { Development Indicators. } & \\
\end{array}$ \\
\hline
\end{tabular}


Table 1

\begin{tabular}{|c|c|c|c|}
\hline Author(s) & Sample & Institutions aspects considered \& sources & Main results \\
\hline $\begin{array}{l}\text { Addison \& } \\
\text { Heshmati } 2003\end{array}$ & 110 countries & Democracy; Freedom House. & Democracy has a positive effect on FDI. \\
\hline Asiedu 2002 & $\begin{array}{l}71 \text { developing countries. } \\
1988-97\end{array}$ & Political risk; Barro \& Lee 1993. Expropriation risk; ICRG PRS. & Political risk and expropriation risk have no significant effects on FDI. \\
\hline $\begin{array}{l}\text { Busse \& \& } \\
\text { Hefeker } 2005\end{array}$ & $\begin{array}{l}83 \quad \text { developing } \\
\text { countries.1984-2003. }\end{array}$ & $\begin{array}{l}12 \text { subcomponents of ICRG, Investment profile, internal and external } \\
\text { conflict, ethnic and religious tension, rule of law, democracy, Military in } \\
\text { politics Government stability, Socio-economic conditions, Quality } \\
\text { bureaucracy, Corruption. }\end{array}$ & $\begin{array}{l}\text { Government stability, the absence of internal conflict and ethnic tensions, basic democratic } \\
\text { rights and ensuring law and order are highly significant determinants of FDI }\end{array}$ \\
\hline $\begin{array}{l}\text { Drabek \&Payne } \\
1999\end{array}$ & 49 countries 1991-95. & ICRG Political Risk Index; PRS. & $\begin{array}{l}\text { A nation that takes steps to increase the degree of transparency in its policies and } \\
\text { institutions could expect significant increase in FDI inflows. }\end{array}$ \\
\hline $\begin{array}{l}\text { Gastanaga et al } \\
1998\end{array}$ & $\begin{array}{ll}22 & \text { less-developed } \\
\text { countries.1970-95. }\end{array}$ & $\begin{array}{l}\text { Nationalization risk, Contract enforcement, Bureaucratic delay; Business } \\
\text { Environmental Risk Intelligence. BERI. Corruption; Mauro } 1995 .\end{array}$ & Different institutional characteristics are shown to have significant effects on FDI. \\
\hline
\end{tabular}




\begin{tabular}{|c|c|c|c|}
\hline $\begin{array}{l}\text { Globerman \& } \\
\text { Shapiro } 2002\end{array}$ & 144 countries $1995-97$ & $\begin{array}{l}\text { Governance Index, Rule of law, Political instability Regulatory quality, } \\
\text { Gove.t effectiveness, Graft and corruption, Voice and accountability; } \\
\text { Kaufmann et al } 1999\end{array}$ & $\begin{array}{l}\text { The general Governance Index is more important than its subcomponent and than Human } \\
\text { development index and Infrastructure index. }\end{array}$ \\
\hline $\begin{array}{l}\text { Harms } \& \\
\text { Ursprung } 2002\end{array}$ & $\begin{array}{l}62 \quad \text { developing } \quad \& \\
\text { emerging-market } \\
\text { countries. 1989-97 }\end{array}$ & $\begin{array}{l}\text { Democracy; Freedom House. Political risk: expropriation, exchange } \\
\text { control, and contract repudiation; ICRG. Business Environment: } \\
\text { corruption, bureaucratic quality and law and order; ICRG PRS. }\end{array}$ & $\begin{array}{l}\text { FDI appear to be attracted by countries in which civil and political freedom is respected. } \\
\text { Other institutional aspects do not have robust effects on FDI. }\end{array}$ \\
\hline Jensen 2003 & 114 countries. $1970-97$. & $\begin{array}{l}\text { Democracy; Polity III data Jagger \& Gurr 1996, Government Reputation, } \\
\text { Expropriation, Corruption, Rule of law, Bureaucratic quality; Easterly } \\
\text { Data Set Easterly } 1999 .\end{array}$ & $\begin{array}{l}\text { Democracy has a robust positive effect on FDI. Other institutional aspects have no } \\
\text { significant effects on FDI or on the effect of democracy on FDI. }\end{array}$ \\
\hline $\begin{array}{l}\text { Jun \& Singh } \\
1996\end{array}$ & 31 countries. 1970-93. & $\begin{array}{lrrrr}\text { Political risk, Operational risk; } & \text { Business } & \text { Environmental } & \text { Risk } \\
\text { Intelligence. BERI. Political rights; Freedom House. } & & \end{array}$ & Institutional aspects have positive but not robust effects on FDI. \\
\hline $\begin{array}{l}\text { Kolstad \& } \\
\text { Tondel } 2002\end{array}$ & $\begin{array}{l}61 \text { developing countries } \\
1989-2000 \text {. }\end{array}$ & $\begin{array}{l}12 \text { subcomponents of ICRG, Investment profile, internal and external } \\
\text { conflict, ethnic and religious tension, rule of law, democracy, Military in } \\
\text { politics Government stability, Socio-economic conditions, Quality } \\
\text { bureaucracy, Corruption. }\end{array}$ & $\begin{array}{l}\text { Foreign investors are concerned about and deterred by ethnic tension and internal conflict } \\
\text { in a country. They pay less attention to external conflict, law and order and military in } \\
\text { politics. Government stability and bureaucratic quality do not matter for FDI. Democracy } \\
\text { is a very robust determinant of FDI. }\end{array}$ \\
\hline $\begin{array}{l}\mathrm{Li} \& \text { Resnick } \\
2003\end{array}$ & $\begin{array}{l}53 \text { developing countries. } \\
\text { 1982-95 }\end{array}$ & Democracy; Polity IV. Property rights protection; Knack \& Keefer 1995. & $\begin{array}{l}\text { Democratic institutions affect FDI inflows both positively, by improving property rights, } \\
\text { and negatively, by imposing constraints on FDI and host country's government. }\end{array}$ \\
\hline $\begin{array}{l}\text { Meon \& Sekkat } \\
2004\end{array}$ & 107 countries. & $\begin{array}{l}\text { ICRG Political Risk Index; PRS, Corruption; Transparency International } \\
\text { \& Rule of law \& Government effectiveness index; Kaufmann et al } 1999 .\end{array}$ & $\begin{array}{l}\text { It is Political risk in general that determines FDI not only one aspect of institutions such as } \\
\text { corruption. }\end{array}$ \\
\hline $\begin{array}{l}\text { Noorbakhsh et } \\
\text { al } 2001\end{array}$ & $\begin{array}{l}36 \text { developing countries } \\
1980-94 .\end{array}$ & Democracy; Freedom House, Political instability; Euromoney. & Democracy and political risk have no significant effect on FDI. \\
\hline
\end{tabular}




\section{Table 2}

\begin{tabular}{|c|c|c|c|c|c|c|c|c|c|c|c|c|c|c|c|}
\hline Model & 1 & 2 & 3 & 4 & 5 & 6 & 7 & 8 & 9 & 10 & 11 & 12 & 13 & 14 & 15 \\
\hline Lagged FDI & - & - & - & - & - & - & - & - & - & - & - & - & $\begin{array}{c}0.116 \\
(1.68)^{*}\end{array}$ & $\begin{array}{c}0.287 \\
(3.97)^{* * *}\end{array}$ & - \\
\hline GDP & $\begin{array}{c}0.654 \\
(7.18)^{* * *}\end{array}$ & $\begin{array}{c}0.720 \\
(7.04)^{* * *}\end{array}$ & $\begin{array}{c}0.359 \\
(2.68)^{* * *}\end{array}$ & $\begin{array}{c}0.444 \\
(2.69)^{* * *}\end{array}$ & $\begin{array}{c}0.484 \\
(2.75)^{* * *}\end{array}$ & $\begin{array}{c}0.521 \\
(2.87)^{* * *}\end{array}$ & $\begin{array}{c}0.528 \\
(2.94)^{* * *}\end{array}$ & $\begin{array}{c}0.815 \\
(4.02)^{* * *}\end{array}$ & $\begin{array}{c}0.521 \\
(2.92)^{* * *}\end{array}$ & $\begin{array}{c}0.780 \\
(3.43)^{* * *}\end{array}$ & $\begin{array}{c}0.521 \\
(1.75)^{*}\end{array}$ & $\begin{array}{c}0.814 \\
(7.77)^{* * *}\end{array}$ & $\begin{array}{c}1.140 \\
(2.23)^{* *}\end{array}$ & $\begin{array}{c}0.494 \\
(2.86) * * *\end{array}$ & $\begin{array}{c}0.432 \\
(7.77)^{* * *}\end{array}$ \\
\hline GDP Growth & - & - & - & - & - & $\begin{array}{c}0.047 \\
(2.34)^{* *}\end{array}$ & $\begin{array}{c}0.047 \\
(2.31)^{* *}\end{array}$ & $\begin{array}{c}0.056 \\
(2.11)^{* *}\end{array}$ & $\begin{array}{c}0.050 \\
(2.48)^{* *}\end{array}$ & $\begin{array}{c}0.060 \\
(2.12)^{* *}\end{array}$ & $\begin{array}{l}0.029 \\
(1.02)\end{array}$ & $\begin{array}{l}0.018 \\
(0.64)\end{array}$ & $\begin{array}{c}0.077 \\
(1.91)^{*}\end{array}$ & $\begin{array}{l}0.042 \\
(1.01)\end{array}$ & $\begin{array}{l}0.033 \\
(0.64)\end{array}$ \\
\hline Trade Ratio & $\begin{array}{c}0.762 \\
(4.11)^{* * *}\end{array}$ & $\begin{array}{c}0.694 \\
(3.38)^{* * *}\end{array}$ & $\begin{array}{c}0.556 \\
(2.67)^{* * *}\end{array}$ & $\begin{array}{c}0.404 \\
(1.84)^{*}\end{array}$ & - & - & - & - & - & - & - & - & - & - & - \\
\hline Institutions & $\begin{array}{c}0.052 \\
(7.48)^{* * *}\end{array}$ & $\begin{array}{c}0.045 \\
(6.24)^{* * *}\end{array}$ & $\begin{array}{c}0.033 \\
(4.51)^{* * *}\end{array}$ & $\begin{array}{c}0.028 \\
(3.62)^{* * *}\end{array}$ & $\begin{array}{c}0.019 \\
(2.94)^{* * *}\end{array}$ & $\begin{array}{c}0.016 \\
(2.34)^{* *}\end{array}$ & $\begin{array}{c}0.015 \\
(2.28)^{* *}\end{array}$ & $\begin{array}{c}0.017 \\
(1.99)^{* *}\end{array}$ & $\begin{array}{c}0.015 \\
(2.14)^{* *}\end{array}$ & $\begin{array}{c}0.024 \\
(2.19)^{* *}\end{array}$ & $\begin{array}{c}0.026 \\
(2.85)^{* * *}\end{array}$ & $\begin{array}{c}0.028 \\
(3.93)^{* * *}\end{array}$ & $\begin{array}{c}0.025 \\
(2.40)^{* *}\end{array}$ & $\begin{array}{c}0.031 \\
(2.78)^{* * *}\end{array}$ & $\begin{array}{c}0.155 \\
(3.93)^{* * *}\end{array}$ \\
\hline Inflation & - & $\begin{array}{c}-0.001 \\
(-7.29)^{* * *}\end{array}$ & $\begin{array}{c}-0.001 \\
(-7.41)^{* * *}\end{array}$ & $\begin{array}{c}-0.001 \\
(-5.81)^{* * *}\end{array}$ & $\begin{array}{c}-0.001 \\
(-6.65)^{* * *}\end{array}$ & $\begin{array}{c}-0.001 \\
(-6.23)^{* * *}\end{array}$ & $\begin{array}{c}-0.001 \\
(-6.34)^{* * *}\end{array}$ & $\begin{array}{c}-0.001 \\
(-6.29)^{* * *}\end{array}$ & $\begin{array}{c}-0.001 \\
(-6.24)^{* * *}\end{array}$ & $\begin{array}{c}-0.001 \\
(-6.06)^{* * *}\end{array}$ & $\begin{array}{c}-0.001 \\
(-4.61)^{* * *}\end{array}$ & $\begin{array}{c}-0.001 \\
(-3.20)^{* * *}\end{array}$ & $\begin{array}{c}-0.0003 \\
(-1.24)\end{array}$ & $\begin{array}{l}-0.0002 \\
(-0.76)\end{array}$ & $\begin{array}{c}-0.1210 \\
(-3.20) * * *\end{array}$ \\
\hline Infrastructure & - & - & $\begin{array}{c}0.006 \\
(5.52)^{* * *}\end{array}$ & $\begin{array}{c}0.006 \\
(4.75)^{* * *}\end{array}$ & $\begin{array}{c}0.005 \\
(4.17)^{* * *}\end{array}$ & $\begin{array}{c}0.004 \\
(4.01)^{* * *}\end{array}$ & $\begin{array}{c}0.004 \\
(3.99)^{* * *}\end{array}$ & $\begin{array}{c}0.002 \\
(1.79)^{*}\end{array}$ & $\begin{array}{c}0.005 \\
(4.25)^{* * *}\end{array}$ & $\begin{array}{l}0.001 \\
(0.68)\end{array}$ & $\begin{array}{c}0.004 \\
(2.81)^{* * *}\end{array}$ & $\begin{array}{c}0.002 \\
(1.70)^{*}\end{array}$ & $\begin{array}{c}0.0005 \\
(0.23)\end{array}$ & $\begin{array}{l}0.0018 \\
(1.44)\end{array}$ & $\begin{array}{c}0.0838 \\
(1.70)^{*}\end{array}$ \\
\hline Income Tax & - & - & - & $\begin{array}{c}-0.016 \\
(-2.71)^{* * *}\end{array}$ & $\begin{array}{c}-0.011 \\
(-1.77)^{*}\end{array}$ & $\begin{array}{c}-0.010 \\
(-1.66)^{*}\end{array}$ & $\begin{array}{l}-0.008 \\
(-1.29)\end{array}$ & $\begin{array}{l}-0.007 \\
(-1.05)\end{array}$ & $\begin{array}{l}-0.010 \\
(-1.53)\end{array}$ & $\begin{array}{l}-0.006 \\
(-0.82)\end{array}$ & $\begin{array}{l}-0.011 \\
(-1.32)\end{array}$ & $\begin{array}{l}-0.002 \\
(-0.58)\end{array}$ & $\begin{array}{l}-0.004 \\
(-0.56)\end{array}$ & $\begin{array}{c}-0.0005 \\
(-0.09)\end{array}$ & $\begin{array}{l}-0.0192 \\
(-0.58)\end{array}$ \\
\hline Tariff & - & - & - & - & $\begin{array}{c}-0.033 \\
(-4.48)^{* * *}\end{array}$ & $\begin{array}{c}-0.033 \\
(-4.46)^{* * *}\end{array}$ & $\begin{array}{c}-0.031 \\
(-4.50)^{* * *}\end{array}$ & $\begin{array}{c}-0.036 \\
(-4.86)^{* * *}\end{array}$ & $\begin{array}{c}-0.033 \\
(-4.42)^{* * *}\end{array}$ & $\begin{array}{c}-0.039 \\
(-5.35)^{* * *}\end{array}$ & $\begin{array}{c}-0.037 \\
(-5.01)^{* * *}\end{array}$ & $\begin{array}{c}-0.037 \\
(-9.97)^{* * *}\end{array}$ & $\begin{array}{l}-0.016 \\
(-1.60)\end{array}$ & $\begin{array}{c}-0.025 \\
(-4.13)^{* * *}\end{array}$ & $\begin{array}{l}-0.263 \\
(-9.97)\end{array}$ \\
\hline Exchange Rate Distortion & - & - & - & - & - & - & $\begin{array}{l}0.030 \\
(1.02)\end{array}$ & - & - & & - & & - & - & - \\
\hline Government Size & - & - & - & - & - & - & - & $\begin{array}{l}-0.007 \\
(-0.97)\end{array}$ & - & - & - & & - & - & - \\
\hline Wages & - & - & - & - & - & - & - & - & $\begin{array}{l}-0.026 \\
(-0.12)\end{array}$ & - & - & & - & - & - \\
\hline Human Capital & - & - & - & - & - & - & - & - & & $\begin{array}{c}1.359 \\
(2.10)^{* *}\end{array}$ & - & & - & - & - \\
\hline Natural Resources Abundance & - & - & - & - & - & - & - & - & - & - & $\begin{array}{l}0.006 \\
(0.59)\end{array}$ & & & & - \\
\hline $\mathbf{R} 2$ & 0.568 & 0.577 & 0.577 & 0.643 & 0.678 & 0.681 & 0.682 & 0.732 & 0.702 & 0.729 & 0.700 & 0.724 & - & - & 0.724 \\
\hline Number of groups & 107 & 102 & 102 & 82 & 82 & 82 & 82 & 55 & 80 & 51 & 66 & 76 & 64 & 80 & 76 \\
\hline
\end{tabular}

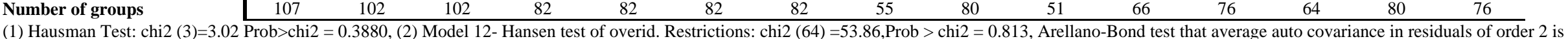

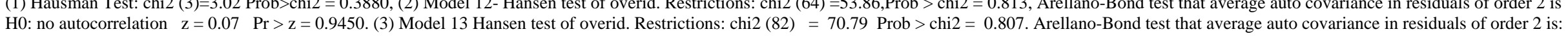

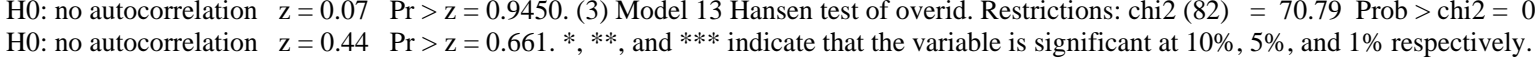


Table 3

\begin{tabular}{l|cccc}
\multicolumn{1}{c|}{ Model } & $\mathbf{1}$ & $\mathbf{2}$ & $\mathbf{3}$ & $\mathbf{4}$ \\
\hline Lagged FDIpc & - & - & 0.100 & 0.321 \\
GDPpc & & & $(1.88)^{\star}$ & $(3.62)^{\star \star \star}$ \\
GDP Growth & 0.476 & 0.832 & 0.879 & 0.530 \\
& $(2.65)^{\star \star \star}$ & $(8.15)^{\star \star \star}$ & $(1.38)$ & $(2.78)^{\star \star \star}$ \\
Inflation & - & 0.012 & 0.043 & 0.030 \\
& & $(0.44)$ & $(1.82)^{\star}$ & $(0.86)$ \\
Infrastructure & -0.001 & -0.001 & -0.0004 & -0.0003 \\
& $(-6.49)^{\star \star \star}$ & $(-3.40)^{\star \star \star}$ & $(-1.42)$ & $(-1.38)$ \\
Income Tax & 0.005 & 0.002 & 0.003 & 0.002 \\
& $(4.49)^{\star \star \star}$ & $(1.83)^{\star}$ & $(1.12)$ & $(1.37)$ \\
Tariff & -0.012 & -0.004 & -0.012 & 0.0001 \\
& $(-1.94)^{\star}$ & $(-0.99)$ & $(-1.31)$ & $(0.01)$ \\
Property Rights & -0.035 & -0.039 & -0.026 & -0.025 \\
& $(-4.69)^{\star \star \star}$ & $(-11.02)^{\star \star \star}$ & $(-3.17)^{\star \star \star}$ & $(-3.84)^{\star \star \star}$ \\
Bureaucracy \&Corruption & 0.080 & 0.139 & 0.180 & 0.154 \\
& $(1.73)^{\star}$ & $(2.76)^{\star \star \star}$ & $(2.25)^{\star \star}$ & $(2.48)^{\star \star}$ \\
Democracy & 0.023 & 0.029 & 0.011 & -0.003 \\
& $(0.45)$ & $(1.04)$ & $(0.17)$ & $(-0.05)$ \\
Constant & -0.008 & -0.014 & 0.005 & 0.011 \\
R2 & $(-0.23)$ & $(-0.55)$ & $(0.06)$ & $(0.23)$ \\
Number of groups & -0.268 & -3.229 & - & -2.480 \\
Number of observations & 0.672 & 0.719 & - & - \\
Nuyyyy & 82 & 76 & 64 & 80 \\
\cline { 2 - 6 } & $\mathbf{2 3 8}$ & $\mathbf{2 2 4}$ & $\mathbf{1 8 1}$ & $\mathbf{2 7 0}$
\end{tabular}

(1) Model1 Arellano-Bond test for AR(2) in first differences: $z=-0.13 \operatorname{Pr}>z=0.898$, Hansen test of overid. Restrictions: $\operatorname{chi} 2(74)=51.46$ Prob $>$ chi2 $=0.979$. (2) Model 2 Arellano-Bond test for AR (2) in first differences: $z$ $=0.23 \operatorname{Pr}>\mathrm{z}=0.819$. Hansen test of overid. Restrictions: chi2 (98) $=70.54$ Prob $>$ chi2 $=0.984$

Table 4

\begin{tabular}{|l|l|l|l|l|}
\hline & Institutions & FDI Primary & FDI & FDI Service \\
& & & & \\
\hline Institutions & 1.00 & - & - & - \\
\hline FDI Primary & 0.25 & 1.00 & - & - \\
\hline FDI & & & 1.00 & - \\
\hline Manufacturing & 0.71 & 0.38 & & 1.00 \\
\hline FDI Service & 0.77 & 0.31 & 0.72 & \\
\hline
\end{tabular}


Table 5

\begin{tabular}{l|ccc}
\multicolumn{1}{c|}{ Model } & $\mathbf{1}$ & $\mathbf{2}$ & $\mathbf{3}$ \\
\hline Institutions & 0.070 & 0.033 & 0.025 \\
Natural Resources Abundance & $(3.31)^{\star \star \star}$ & $(1.51)$ & $(1.33)$ \\
& - & 0.122 & 0.118 \\
Tax & & $(7.70)^{\star \star \star}$ & $(7.42)^{\star \star \star}$ \\
& - & -0.055 & -0.057 \\
Infrastructure & & $(-3.73)^{\star \star \star}$ & $(-3.44)^{\star \star \star}$ \\
Constant & - & 0.161 & 0.209 \\
R2 & & $(1.01)$ & $(1.12)$ \\
Number of groups & -3.178 & -0.795 & -0.225 \\
Number of observations & 0.054 & 0.510 & 0.499 \\
\cline { 2 - 4 } & 55 & 46 & 45 \\
\cline { 2 - 4 } & $\mathbf{1 4 2}$ & $\mathbf{1 1 5}$ & $\mathbf{1 0 9}$
\end{tabular}

Table 6

\begin{tabular}{l|ccc}
\multicolumn{1}{c|}{ Model } & $\mathbf{1}$ & $\mathbf{2}$ & $\mathbf{3}$ \\
\hline Institutions & 0.092 & 0.063 & 0.031 \\
Market size & $(12.18)^{\star \star \star}$ & $(5.91)^{\star \star \star}$ & $(3.13)^{\star \star \star}$ \\
& - & 0.052 & 0.065 \\
Trade Ratio & & $(2.37)^{\star \star}$ & $(3.04)^{\star \star \star}$ \\
& - & 0.005 & 0.006 \\
Inflation & & $(1.48)$ & $(2.70)^{\star \star \star}$ \\
& - & -0.001 & -0.002 \\
Infrastructure & & $(-4.00)^{\star \star \star}$ & $(-4.68)^{\star \star \star}$ \\
& - & 0.262 & 0.360 \\
Tax & & $(2.12)^{\star \star}$ & $(2.72)^{\star \star \star}$ \\
& - & -0.002 & -0.006 \\
Constant & & $(-0.28)$ & $(-0.71)$ \\
R2 & -3.615 & -3.970 & -2.392 \\
Number of groups & 0.453 & 0.628 & 0.591 \\
Number of observations & $\mathbf{1 4 9}$ & 49 & 48 \\
\cline { 2 - 4 } Numy & $\mathbf{1 2 1}$ & $\mathbf{1 1 5}$
\end{tabular}


Table 7

\begin{tabular}{|c|c|c|c|c|}
\hline Model & 1 & 2 & 3 & 4 \\
\hline$\overline{\text { Institutions }}$ & $\begin{array}{c}0.140 \\
(9.84)^{\star \star \star}\end{array}$ & $\begin{array}{c}0.070 \\
(5.20)^{\star * \star}\end{array}$ & $\begin{array}{c}0.031 \\
(2.16)^{\star \star}\end{array}$ & $\begin{array}{c}0.023 \\
(1.81)^{\star}\end{array}$ \\
\hline Market size & - & $\begin{array}{c}0.049 \\
(2.42)^{\star \star}\end{array}$ & $\begin{array}{c}0.056 \\
(3.15)^{\star \star \star}\end{array}$ & $\begin{array}{l}0.032 \\
(1.40)\end{array}$ \\
\hline Trade Ratio & - & $\begin{array}{c}0.012 \\
(2.62)^{\star \star *}\end{array}$ & $\begin{array}{c}0.014 \\
(3.33)^{\star \star \star}\end{array}$ & $\begin{array}{c}0.017 \\
(3.51)^{\star \star \star}\end{array}$ \\
\hline Inflation & - & $\begin{array}{c}-0.001 \\
(-4.00)^{\star \star}\end{array}$ & $\begin{array}{l}0.0001 \\
(0.34)\end{array}$ & $\begin{array}{c}-0.001 \\
(-6.44)^{\star \star \star}\end{array}$ \\
\hline Infrastructure & - & $\begin{array}{c}0.343 \\
(2.17)^{\star \star}\end{array}$ & $\begin{array}{l}0.037 \\
(0.27)\end{array}$ & $\begin{array}{c}0.579 \\
(4.36)^{\star \star \star}\end{array}$ \\
\hline $\operatorname{tax}$ & - & $\begin{array}{c}-0.026 \\
(-3.38)^{\star \star \star}\end{array}$ & $\begin{array}{c}-0.022 \\
(-3.43)^{\star \star \star}\end{array}$ & $\begin{array}{c}-0.034 \\
(-3.60)^{\star \star \star}\end{array}$ \\
\hline Manufacturing FDI & - & - & $\begin{array}{c}0.621 \\
(5.67)^{\star \star \star}\end{array}$ & - \\
\hline Constant & -6.414 & -5.679 & -3.881 & -2.636 \\
\hline R2 & 0.511 & 0.606 & 0.707 & 0.518 \\
\hline Number of groups & 57 & 49 & 48 & 48 \\
\hline Number of observations & 151 & 124 & 118 & 118 \\
\hline
\end{tabular}

Table 8

\begin{tabular}{|c|c|c|c|c|c|c|}
\hline & \multicolumn{3}{|c|}{1990} & \multicolumn{3}{c|}{2002} \\
\hline & Primary & Manufacturing & Service & Primary & Manufacturing & Service \\
\hline World & 9 & 42 & 49 & 6 & 34 & 60 \\
\hline Developed countries & 10 & 41 & 49 & 6 & 32 & 62 \\
\hline Developing countries & 7 & 46 & 47 & 7 & 38 & 55 \\
\hline
\end{tabular}

